\title{
Dietary Habits in School Children (9-12 Years Old) with Normal Nutritional Status an a Mediterranean Area
}

\author{
Teodoro Durá-Travé ${ }^{1,2 *}$, Fidel Gallinas-Victoriano² and Beatriz Durá-Gúrpide \\ ${ }^{1}$ Department of Pediatrics, Faculty of Medicine, University of Navarra, Spain \\ ${ }^{2}$ Deparment of Pediatrics, Navarra Hospital Complex, Pamplona, Spain
}

\begin{abstract}
Objectives: To achieve a descriptive study of dietary habits in a group of students of primary education (9-12 years old) with normal nutritional status.

Material and methods: A nutrition survey was carried out (food intake registration of two consecutive school days) in a selected group of 353 schoolchildren (188 males and 165 females) with normal nutritional status (body mass index should range between +1 and -1 standard deviations).

Results: The average age of the surveyed students was 10.5 years (Cl 95\%: 10.3-11.7). There were no significant differences between both sexes in mean values for weight, height, BMI and calorie intake (males: 2072.7 \pm 261.7 and females: $2060.9 \pm 250.6)$. Cereals $(34 \%)$ dairy products $(19 \%)$ and meats $(17 \%)$ were responsible of approximately $70 \%$ of total calorie intake. Protein accounted for $20.3 \%$ of energy intake, carbohydrates for $48.8 \%$, total fat for $30.9 \%$, and saturated fat for $12.6 \%$. Cholesterol intake was excessive and over two-thirds of protein intake was from animal sources. In both sexes, the mean intakes of calcium, iodine and vitamins $A$, D and $E$ were below recommended levels.
\end{abstract}

Conclusions: The dietary patterns of the schoolchildren with normal nutritional status differed from the Mediterranean diet. Intakes of meat and sugar were too high and dairy products and cereals consumption was relatively limited, while that of vegetables, legumes, fruits and fish were insufficient, leading to excessive protein and fat intake from animal sources and insufficient mineral (calcium and iodine) and vitamins A, D and E intake.

Keywords: Dietary patterns; Food intake; School children; Nutritional status

\section{Introduction}

Dietary habits have always been a social and cultural referent of the different societies. However, scientific evidence in the past years associating diet and health condition has been essential in order to consider dietary habits of a concrete population as a social and sanitary indicator [1]. The nutrition habits traditionally observed in some countries of the Mediterranean area have created the concept of "Mediterranean diet", whose nutritional interest stands in the variety of foods included in it-in fact, every food group is allowed always an adequate Proportion- and the balanced calorie as well as nutrient intake they guarantee, through a combination of fruits and vegetables with bread, pasta and rice, as well as legumes with dairy products, fish and red meat and olive oil as a cooking fat [2-5].

Nevertheless, industrialization and marketing of the food chain in western countries, increasing production of processed food, are leading to a series of changes in dietary habits and preferences in wide sectors of the population. Society has accepted an occidental dietary pattern characterized by an excessive intake of food of animal origin, especially meat and derivatives, and added sugars, at the expense of the intake of cereals, vegetables and fruits. This fact is leading to an increase of saturated fat and cholesterol in diet [6-8]. This virtual deterioration of dietary patterns in our social and cultural environment has feared a gradual disappearance of Mediterranean diet [9] and would justify, to a great extent, the study of the quality of dietary habits in general population and, especially, in those sectors of population more susceptible of being influenced, such as infant population. On the other side, we assume that schoolchildren with normal nutritional status have dietary habits that guarantee the necessary energy and nutrient requirements without deficiencies or excess and that they would contribute to the prevention of adult diseases such as ischemic coronary disease, atherosclerosis, osteoporosis, obesity, diabetes, high blood pressure, etc [10-15].

The aim of this work is to achieve a descriptive study of dietary habits in a group of students of primary education with normal nutritional status, as well as to analyze the adequacy of energy and nutrient intake in these schoolchildren to the established nutrition requirements in order to design nutrition intervention strategies.

\section{Material and Methods}

\section{Patients}

A nutritional survey has been conducted in a selected group of 353 students (188 males and 165 females) of primary education (3rd to 6th grade: 9-12 years old) in the city of Pamplona, who assisted for consultation to the Pediatric Department in the Complejo Hospitalario de Navarra in 2012 (surveys were undertaken in the January-June period). All those schoolchildren who suffered from any acute of chronic disease which might condition their nutrition status, those who use energy and/or vitamin and mineral supplements and all those students who had lunch out of their own home (home of relatives, school lunch, etc.) were excluded. The normality of the nutrition status

*Corresponding author: Durá-Travé T, Department of Pediatrics, Faculty of Medicine, University of Navarra, Avenue Irunlarrea, Pamplona, Spain, Tel: +34 848-422563; Fax: +34 8484299 24; E-mail: tduratra@cfnavarra.es

Received December 12, 2013; Accepted February 17, 2014; Published February 19,2014

Citation: Durá-Travé T, Gallinas-Victoriano F, Durá-Gúrpide B (2014) Dietary Habits in School Children (9-12 Years Old) with Normal Nutritional Status an a Mediterranean Area. J Nutr Disorders Ther 4: 133. doi:10.4172/2161-0509.1000133

Copyright: @ 2014 Durá-Travé T, et al. This is an open-access article distributed under the terms of the Creative Commons Attribution License, which permits unrestricted use, distribution, and reproduction in any medium, provided the original author and source are credited. 
was the condition sine qua non to be included in this study; this means, Body Mass Index (BMI) should range between +1 and -1 standard deviations.

\section{Nutrition survey}

The nutrition survey was carried out in the form of personal interview using a food intake registration of two consecutive school days. Every study participant was asked about food intake in every meal during the previous three consecutive days (breakfast, mid-morning snack, lunch, afternoon snack and supper). A photograph album with portions and measures from the Institut Scientifique et Technique de la Nutrition et de l'Alimentation (Paris, 2002) [16] was used to calculate the size of the corresponding portions of the different foods that the participants referred to have eaten.

The foods were divided into the following groups:

1) Milk and dairy products

2) Cereals and cereal products

3) Sweets, bakery and pastry

4) Fruits and natural juices

5) Fats and oils

6) Meat and derivatives

7) Eggs and derivatives

8) Vegetables, tubers and legumes

9) Fishes

Energy and nutrient consumption (proteins, carbohydrates, total fat, saturated fatty acid SFA, Monounsaturated Fatty Acids (MUFA) and Polyunsaturated Fatty Acids (PUFA), total fibre and cholesterol), minerals (calcium, iron, iodine, magnesium, zinc, selenium, and phosphorus), and vitamins (thiamine, riboflavin, niacin, vitamin B6, folate, vitamin B12, vitamin $\mathrm{C}$, vitamin $\mathrm{A}$, vitamin $\mathrm{D}$ and vitamin $\mathrm{E}$ ) was calculated using the CESNID $1.0^{\circledR}$ nutrition calculation program (Centro de Enseñanza Superior de Nutrición y Dietética. Universidad de Barcelona) [17]. The reference values for minerals and vitamins Dietary Reference Intake (DRI) in different ages are the updated tables of the National Academy of Sciences [18]

\section{Nutrition study}

Sex, age, weight and height from every school children were recorded. Weight and height assessment were done in underclothes and shoes off. Weight was measured using an Año-Sayol ${ }^{\mathbb{B}}$ scale (read range $0-120 \mathrm{~kg}$ and precision $100 \mathrm{~g}$ ) and height was measured using a wall mounted rigid stadiometer (ranking 60-210 cm and with $0.1 \mathrm{~cm}$ precision). Body Mass Index (BMI) Z-scores were calculated using the SEINAPTRACKER program (Medicalsoft Intercath, S.L. Universidad de Barcelona, 2007-2008). Reference growth curves and charts were the Centro Andrea Prader (Zaragoza, 2004) charts.

\section{Statistical analysis}

Results are shown as means (M) and percentages (\%) with corresponding standard deviations (SD) of confidence intervals $(95 \%$ CI). The SPSS version 20.0 (Chicago, Illinois, USA) program was used for statistics and analysis (Student's T test, comparisons of proportions). Statistical significance was assumed for a $\mathrm{p}$ value lower than 0.05 .

\section{Results}

\section{Characteristics of the sample}

The average age of the surveyed students was 10.5 years (CI 95\%: 10.3-11.7), and there were no statistically significant differences between both sexes. In the same way, there were no significant differences in mean values for weight (males: $38.8 \pm 0.8$ and females: $39.0 \pm 0.7$ ), height (males: $143 \pm 0.6$ and females: $142.8 \pm 0.7$ ) and BMI (males: 18.6 \pm 0.1 and females: $18.42 \pm 0.3$ ). All survey respondents related to have lunch and dinner; however, $1.1 \%(n=4), 5.9 \%(n=21)$ and $3.1 \%(n=11)$ refer not having breakfast, lunch or afternoon snack, respectively.

\section{Consumption frequencies}

Table 1 displays the consumption frequencies of the different food groups of every daily intake of the totality of the surveyed members of the sample (there were no statistically significant differences among sexes). As for breakfast, dairy products (91.5\%), sweets, bakery and pastry $(50 \%)$ and/or cereals $(43 \%)$ and, to a lesser extent; fruits and natural juices (14\%) and fats and oils (12\%) were the food groups with a higher consumption. In addition, $72 \%$ and $15 \%$ of the respondents referred the addition of cocoa powder and sugar to milk, respectively.

As for mid-morning snack, bread (61\%), together with cured meat (46\%), fruits $(12 \%)$ and yoghourt (11\%) were the most consumed foods. As for lunch, meat (74\%), as well as cereals (67\%), dairy products (45\%), fruits (37\%), legumes (30\%) and vegetables (26\%), tubers (18\%) and fish (15\%) were the most consumed foods.

As for mid-afternoon snack, bread (78.2\%), as long with cured meat $(42 \%)$, chocolate and/or cocoa butter $(26 \%)$ and, to a lesser extent, yoghourt (13\%) and fruits (8\%) were the foods with a higher consumption.

As for dinner, dairy products (77\%), meats $(69 \%)$, cereals $(60 \%)$,

\begin{tabular}{|c|c|c|c|c|c|}
\hline Food group & $\begin{array}{c}\text { Breakfast } \\
(\%)\end{array}$ & $\begin{array}{l}\text { Mid-morning } \\
\text { snack }(\%)\end{array}$ & $\begin{array}{c}\text { Lunch } \\
(\%)\end{array}$ & $\begin{array}{l}\text { Afternoon } \\
\text { snak (\%) }\end{array}$ & $\begin{array}{c}\text { Dinner } \\
(\%)\end{array}$ \\
\hline $\begin{array}{c}\text { Dairy products } \\
\text { Milk } \\
\text { Yogurt } \\
\text { Cheese } \\
\text { Others }\end{array}$ & $\begin{array}{l}90,1 \\
3,1 \\
2,0 \\
-\end{array}$ & $\begin{array}{l}- \\
5,4 \\
10,8 \\
-\end{array}$ & $\begin{array}{c}5,1 \\
30,9 \\
4,5 \\
4,5\end{array}$ & $\begin{array}{c}7,1 \\
13,0 \\
3,1 \\
2,0\end{array}$ & $\begin{array}{c}26,1 \\
26,9 \\
18,1 \\
5,9\end{array}$ \\
\hline $\begin{array}{c}\text { Sweets } \\
\text { Cookies } \\
\text { Bakery } \\
\text { Chocolate/cocoa }\end{array}$ & $\begin{array}{l}28,9 \\
20,9 \\
-\end{array}$ & $\begin{array}{l}13,3 \\
13,3 \\
2,0\end{array}$ & $\begin{array}{l}1,1 \\
2,5 \\
-\end{array}$ & $\begin{array}{r}5,1 \\
5,9 \\
26,1\end{array}$ & $\begin{array}{l}5,9 \\
7,9 \\
0,0\end{array}$ \\
\hline $\begin{array}{c}\text { Cereals } \\
\text { Pasta/rice } \\
\text { Breakfast cereals } \\
\text { Bread }\end{array}$ & $\begin{array}{l}- \\
22,9 \\
20,1\end{array}$ & $\begin{array}{l}- \\
- \\
60,9\end{array}$ & $\begin{array}{c}29,2 \\
- \\
52,1\end{array}$ & $\begin{array}{c}- \\
4,0 \\
78,2\end{array}$ & $\begin{array}{c}9,1 \\
2,0 \\
53,0\end{array}$ \\
\hline $\begin{array}{l}\text { Meats } \\
\text { Red meat } \\
\text { Poultry } \\
\text { Cured meat }\end{array}$ & $\begin{array}{l}- \\
- \\
2,0\end{array}$ & $\begin{array}{l}- \\
- \\
45,9\end{array}$ & $\begin{array}{c}44,5 \\
19,8 \\
9,6\end{array}$ & $\begin{array}{c}- \\
- \\
41,9\end{array}$ & $\begin{array}{c}39,9 \\
20,1 \\
9,1\end{array}$ \\
\hline Eggs & 1,1 & 2,0 & 4,5 & 1,1 & 19,0 \\
\hline $\begin{array}{c}\text { Vegetables } \\
\text { Tubers } \\
\text { Legumes }\end{array}$ & $\begin{array}{l}1,1 \\
- \\
-\end{array}$ & $\begin{array}{l}- \\
- \\
-\end{array}$ & $\begin{array}{l}25,5 \\
18,4 \\
30,0\end{array}$ & $\begin{array}{l}- \\
- \\
-\end{array}$ & $\begin{array}{c}24,1 \\
20,1 \\
3,1\end{array}$ \\
\hline $\begin{array}{l}\text { Fruits y zumos } \\
\text { Fruits } \\
\text { Natural juices }\end{array}$ & $\begin{array}{l}1,1 \\
13,0\end{array}$ & $\begin{array}{l}11,9 \\
2,0\end{array}$ & $\begin{array}{c}36,5 \\
-\end{array}$ & $\begin{array}{l}8,2 \\
4,0\end{array}$ & $\begin{array}{c}19,0 \\
-\end{array}$ \\
\hline Fishes & - & - & 15,0 & 1,1 & 15,0 \\
\hline Fat and oils & 11,9 & - & - & - & - \\
\hline
\end{tabular}

Table 1: Consumption frequencies (\%) of the different food groups of every daily intake. 
Citation: Durá-Travé T, Gallinas-Victoriano F, Durá-Gúrpide B (2014) Dietary Habits in School Children (9-12 Years Old) with Normal Nutritional Status an a Mediterranean Area. J Nutr Disorders Ther 4: 133. doi:10.4172/2161-0509.1000133

Page 3 of 6

vegetables (24\%), tubers (20\%), eggs (19\%), fruits (19\%) and fish (15\%) were the foods with a higher consumption.

\section{Nutrients and calorie intake}

Average value of daily calorie intake was $2066.9 \mathrm{Kcal}$ (CI 95\%: 2040.2-2093.6) with no statistically significant differences among sexes (males: $2072.7 \pm 261.7$ and females: $2060.9 \pm 250.6$ ). Table 2 sets out the average value for calorie intake and proportional calorie intake of every daily intake in the surveyed students (there were no statistically significant differences among sexes). The highest calorie contribution corresponds to lunch (34.5\%), followed by breakfast-mid morning snack (27.9\%), dinner (23.5\%) and, finally, mid-afternoon snack (14.5\%).

Figure 1 displays the percentage contribution of the different food groups to daily calorie intake (no statistical differences among sexes). Cereals (34\%) dairy products (19\%) and meats (17\%) were responsible of approximately $70 \%$ of total calorie intake.

Table 3 shows the average values of the intake of macronutrients, minerals and vitamins (there were no statistically significant differences among sexes). The average value of calcium, iodine and vitamins $\mathrm{A}, \mathrm{D}$ and $\mathrm{E}$ were lower than Recommended Dietary Allowances (RDA) for minerals and vitamins, respectively.

Table 4 exposes percentage contributions of the immediate principles and fatty acids to the total calorie intake in every respondent, so making a comparison with a healthy diet prototype. An excessive protein intake is observed mainly from animal origin, a deficient intake of carbohydrates and a higher than recommended intake of fatty acids; there were no significant differences between sexes.

\section{Percentage contribution of food groups}

Table 5 shows the percentage contribution of the different food

\begin{tabular}{|c|c|c|}
\hline Meal & $\begin{array}{c}\text { Calorie intake (Kcal) } \\
\text { M (CI 95\%) }\end{array}$ & $\begin{array}{c}\text { Calorie contribution (\%) } \\
\text { M (CI 95\%) }\end{array}$ \\
\hline Breakfast & $323.5(313.9-333.1)$ & $16.0(15.5-16.5)$ \\
\hline Mid-morning snack & $253.8(242.2-265.4$ & $11.9(11.4-12.4)$ \\
\hline Lunch & $734.2(714.6-753.8)$ & $34.5(33.7-35.4)$ \\
\hline Afternoon snack & $298.1(287.7-308.5)$ & $14.5(14.0-15.0)$ \\
\hline Dinner & $498.2(480.3-516.1)$ & $23.5(22.8-24.2)$ \\
\hline
\end{tabular}

Table 2: Calorie intake (kilocalories) and calorie percentage contribution (\%) of daily meals.

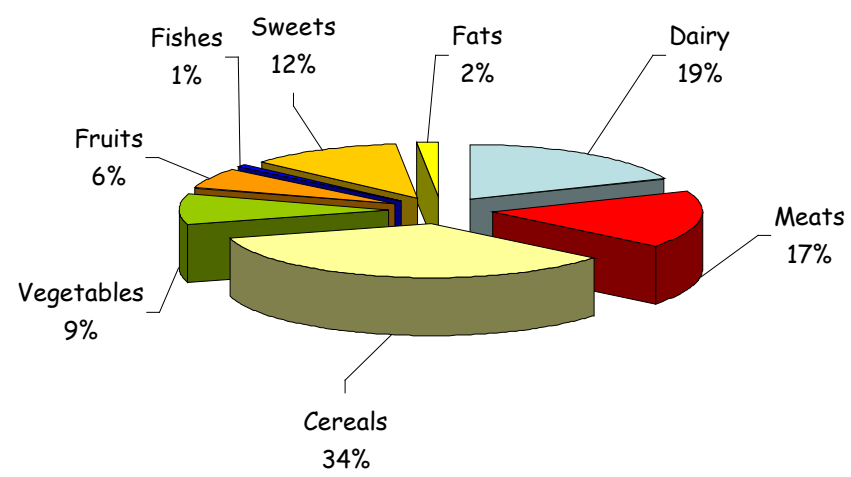

Figure 1: Percentage contribution of the different food groups to daily calorie intake.

\begin{tabular}{|c|c|}
\hline Nutrients & Total group $M \pm S D$ \\
\hline Proteins (g) & $102.90 \pm 22.03$ \\
\hline Carbohydrates (g) & $247.67 \pm 48.90$ \\
\hline Total fat(g) & $69.58 \pm 19.24$ \\
\hline SFA $(g)$ & $28.42 \pm 7.54$ \\
\hline MUFA (g) & $24.55 \pm 8.05$ \\
\hline PUFA (g) & $8.43 \pm 2.62$ \\
\hline Total fibre (g) & $26.51 \pm 13.51$ \\
\hline Cholesterol (mg) & $315.55 \pm 95.93$ \\
\hline Calcium (mg) & $911.74 \pm 174.12$ \\
\hline Iron (mg) & $18.26 \pm 6.03$ \\
\hline lodine $(\mu \mathrm{g})$ & $79.18 \pm 22.67$ \\
\hline Magnesium (mg) & $311.80 \pm 83.36$ \\
\hline Zinc (mg) & $10.49 \pm 2.73$ \\
\hline Selenium $(\mu \mathrm{g})$ & $125.83 \pm 39.66$ \\
\hline Phosphorus (mg) & $1606.82 \pm 294.00$ \\
\hline Thiamine (mg) & $1.68 \pm 0.58$ \\
\hline Riboflavin (mg) & $1.85 \pm 0.51$ \\
\hline Niacin (mg) & $38.96 \pm 7.62$ \\
\hline Vitamin B6(mg) & $2.04 \pm 0.65$ \\
\hline Folate $(\mu \mathrm{g})$ & $334.64 \pm 150.27$ \\
\hline Vitamin B12(mg) & $5.75 \pm 2.55$ \\
\hline Vitamin C (mg) & $54.34 \pm 34.30$ \\
\hline Vitamin A $(\mu \mathrm{g})$ & $463.64 \pm 204.63$ \\
\hline Vitamin D $(\mu \mathrm{g})$ & $88.0 \pm 66.3$ \\
\hline Vitamin E (mg) & $3.81 \pm 1.71$ \\
\hline
\end{tabular}

Table 3: Macronutrients, minerals and vitamins daily intake.

\begin{tabular}{|c|c|}
\hline Nutrients (recommended percentage) & Percentage (\%) \\
\hline Proteins (10-15\%) & 20.3 \\
Animal origin & 64.5 \\
\hline Carbohydrates (50-55\%) & 48.8 \\
\hline Total fat (30-35\%) & 30.9 \\
SFA (7-10\%) & 12.6 \\
MUFA (15-20\%) & 10.9 \\
PUFA (6-10\%) & 3.74 \\
\hline
\end{tabular}

Table 4: Percentage contribution of immediate principles and fatty acids to daily calorie intake in the whole group.

\begin{tabular}{|c|c|c|c|c|c|c|c|c|}
\hline Food groups & Prot. & $\mathrm{CH}$. & Fat & SFA & MUFA & PUFA & Chol. & Fibre \\
\hline Dairy products & 19.7 & 9.0 & 36.9 & 47.5 & 32.4 & 23.8 & 20.2 & - \\
\hline Cereals & 20.8 & 55.0 & 6.4 & 3.2 & 3.3 & 12.3 & - & 36.5 \\
\hline Meats & 38.0 & 2.4 & 27.7 & 22.4 & 33.5 & 27.5 & 42.9 & - \\
\hline Eggs & 2.0 & --- & 3.6 & 2.2 & 4.8 & 3.9 & 21.4 & - \\
\hline $\begin{array}{l}\text { Vegetables } \\
\text { Legumes }\end{array}$ & $\begin{array}{c}0.5 \\
11.5\end{array}$ & $\begin{array}{l}0.7 \\
9.1\end{array}$ & 1.9 & -- & -- & 7.1 & --- & $\begin{array}{c}2.4 \\
37.8\end{array}$ \\
\hline Fruits & 0.7 & 10.6 & 1.4 & --- & 1.8 & 3.0 & --- & 16.9 \\
\hline Fishes & 2.9 & --- & 0.8 & --- & -- & 1.5 & 5.4 & --- \\
\hline Sweets & 3.9 & 13.2 & 15.1 & 18.9 & 14.5 & 9.9 & 8.5 & 6.4 \\
\hline Fat & --- & --- & 6.2 & 4.3 & 7.8 & 11.0 & 1.6 & -- \\
\hline
\end{tabular}

Prot.: Proteins. $\mathrm{CH}$ : Carbohydrates. Chol.: Cholesterol

Table 5: Percentage contribution (\%) of the different food groups to daily macronutrients intake.

groups in daily macronutrients intake. The ingestion of proteins came mainly from meats (38\%), cereals $(20 \%)$ and dairy products $(19.7 \%)$. Carbohydrates from cereals (55\%); lipids from dairy products $(36.9 \%)$ and meats $(27.7 \%)$. SFA came mainly from dairy products $(47.5 \%)$, meats $(22.4 \%)$ and sweets, bakery and pastry (18.9\%); cholesterol from meats (42.9\%), eggs (21.4\%) and dairy products (20.2\%). Finally, fibre 


\begin{tabular}{|c|c|c|c|c|c|c|c|}
\hline $\begin{array}{c}\text { Food } \\
\text { group }\end{array}$ & Calcium & Iron & lodine & Magnesium & Zinc & Selenium & Phosphorus \\
\hline $\begin{array}{c}\text { Dairy } \\
\text { products }\end{array}$ & 71.8 & 2.7 & 43.7 & 20.9 & 19.8 & 5.1 & 35.0 \\
\hline Cereals & 11.6 & 30.2 & 16.6 & 26.8 & 15.0 & 62.4 & 15.2 \\
\hline Meat & 2.4 & 25.1 & 15.5 & 14.0 & 43.5 & 14.2 & 25.5 \\
\hline Eggs & 1.0 & 1.9 & 2.6 & --- & 2.76 & 1.2 & 2.2 \\
\hline $\begin{array}{c}\text { Vegetables } \\
\text { Legumes }\end{array}$ & 4.9 & 1.5 & 2.2 & 1.6 & 14.2 & 4.3 & 14.0 \\
\hline Fruits & 1.4 & 6.6 & 2.6 & 4.7 & 2.1 & 2.1 & 1.6 \\
\hline Fishes & --- & 1.5 & 8.6 & 2.4 & --- & 7.1 & 2.2 \\
\hline Sweets & 5.9 & 7.2 & 6.8 & 3.3 & 1.8 & 3.6 & 4.4 \\
\hline Fat & --- & --- & 1.4 & --- & --- & --- & --- \\
\hline
\end{tabular}

Table 6: Percentage contribution (\%) of food groups to daily mineral intake.

from legumes (37.8\%), cereals (36.5\%) and fruits (16.9\%).

Table 6 shows the percentage contribution of the different food groups to the daily minerals intake. Calcium intake came mainly from dairy products $(71.8 \%)$; iron from cereals $(30.2 \%)$, meats $(25.1 \%)$ and legumes (23.1\%); iodine, from dairy products (43.7\%); magnesium, from cereals $(26.8 \%)$, legumes $(25.5 \%)$ and dairy products $(20.9 \%)$; zinc, from meats $(43.5 \%)$; selenium, from cereals $(62.4 \%)$. Finally, phosphorus from dairy products $(35 \%)$ and meats $(25.5 \%)$.

Table 7 details the percentage contribution from the different food groups in daily vitamins intake. Thiamine (vitamin B1) intake came mainly from meats (29.6\%) cereals (27\%) and legumes (17\%); riboflavin (vitamin B2) from dairy products $(41.3 \%)$, meats $(19.5 \%)$ and cereals (19.4\%); niacin, from meats (42.5\%) and cereals (25.6\%); vitamin B6, from meats $(38 \%)$, cereals $(21.3 \%)$ and legumes $(17.6 \%)$; folate, from legumes (34.9\%) and cereals (30.4\%); vitamin B12, from dairy products (38.3\%) and meats (38.3\%); vitamin A, from dairy products (47.6\%); vitamin C, from fruits (54\%) and cereals (18.4\%); vitamin D, from cereals (43.1\%) and, finally, vitamin E, from legumes (29.8\%) and fruits $(20.8 \%)$.

\section{Discussion}

Nutrition surveys based on recall are an optimal and widely used method in cross sectional studies with descriptive purposes, as in this case. A compendium of food pictures showing servings and sizes was used in order to facilitate the respondents to specify the quantity and/or size of the corresponding servings they had consumed in the previous three days. These pictures allowed both the surveyed students to identify the serving/size and the interviewer to estimate the consumed amounts [16]. These kinds of surveys have important methodological limitations we have tried to correct. On one hand, the option to include a 24 hour recall would have not considered adequately the intra individual variability in the sample; on the other hand, these surveys are somehow dependent on memory and, in addition, especially in this case, on the children's ability to describe the consumed food; that is the reason why the surveyed children were students of $3 \mathrm{rd}$ to 6th grade in primary education (9-12 years old). However, this study has some methodological limitations, since the sampling process was not a random process, but a convenience sampling (patients who assisted for consultation in a concrete period), and so the population representation and, consequently, the external validity would be compromised. Nevertheless, this lack of representation is assumed and the study attempts to make comparisons with internal validity for the people that participated in it.

At present day, the clinical validity of BMI as anthropometric parameter to define nutrition status in childhood and adolescence is admitted [19-21]. Owing to the variability in body composition throughout the pediatric age, specific reference charts are used for different age and sex, being local reference charts whenever available recommended. This nutrition study has used as a reference the charts and tables from Ferrandez et al. (Centro Andrea Prader, Zaragoza 2004), which are widely spread and proved utility in our environment.

Eating habits of surveyed scholars, all of them in normal nutritional status, reflected a dietary model that, even though it covered calorie needs for the corresponding age, it differed slightly from the Mediterranean prototype [2-4]. On the whole, school kids consumed meats and derivatives almost every day and on a recurring basis. Meanwhile, the consumption of food of vegetable origin, such as vegetables, legumes and fruits, was considerably lower, and fish consumption was marginal. Dairy products and cereals consumption was relatively limited. However, sweets, bakery and pastry consumption was slightly high, being responsible for $13.2 \%$ of the whole of carbohydrates. However, the distribution of calorie intake along the five daily meals was adjusted to recommended proportional distribution.

An immediate consequence of the acquisition of this dietary pattern by school children in our environment is the evidence of a clear imbalance in percentage contribution of immediate principles to daily calorie intake. Fat intake, even though quantitatively sufficient since it represented $30.9 \%$ of total calorie intake, showed an excess in SFA to the detriment of MUFA and PUFA; in addition, cholesterol dietary intake, especially in males, exceeded the recommended $300 \mathrm{mg}$ per day. Carbohydrate intake barely represented $48.8 \%$ of total calorie intake; this means, it did not get to the percentage contribution it should represent as a main energetic immediate principle at that age. However, protein intake slightly over passed the established recommendations, since it represented $20.3 \%$ of total calorie intake; furthermore, there was a clear imbalance between animal and vegetable origin, to the point that animal protein intake was responsible for two thirds of total protein intake. Another consequence of this dietary model is a deficient coverage in some minerals and vitamins; in fact, calcium, iodine, vitamin $\mathrm{A}, \mathrm{D}$ and $\mathrm{E}$ intake was below the established recommendations in both sexes. This means, the characteristics of this dietary model do not match the basic concept of a balanced diet, since, despite an adequate energy intake, it does not guarantee sufficient nutrients intake in adequate quantity or proportion to get an optimal nutrition status.

Another characteristic of a balanced diet is the variety and diversity of foods it is made of. However, the dietary model of the surveyed students lacked this distinctive feature; in fact, the majority of nutrients were provided, bur for some exceptions, by the triad: dairy products, cereals and meats. When analyzing the percentage contribution of the

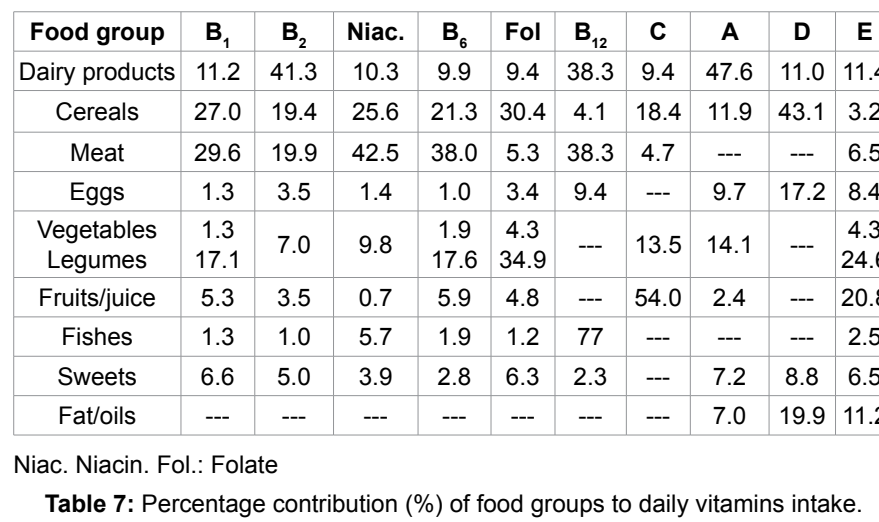


different food groups in nutrients intake, we observe how the intake of proteins, SFA and cholesterol depended, in large measure, on meats and/or cured meat. Although meat is an essential element in any balanced diet as a source of high biological value proteins, minerals (iron, zinc and phosphorus), B-complex vitamins (thiamine, riboflavin, niacin, pyridoxine and cyanocobalamin), it is also a source of SFA (palmitic, stearic, myristic) and cholesterol. That is the reason why it is advisable to relegate lean means and/or poultry consumption to 3-4 servings per week, and fatty meats and/or cured meats to occasional situations. Likewise, dairy products also contribute substantially to protein, saturated fat and cholesterol intake, besides representing the main source of calcium, iodine and vitamin A. However, even though dairy products have a high content in SFA and cholesterol, their consumption should be increased mainly as yoghourts and cheese, with the aim to make up for the deficient calcium and, to a lesser extent, vitamin $\mathrm{A}$ and iodine intake noticed in school kids; when having a normal nutritional status as it happened in this case, low fat and/or modified fat composition dairy products could be consumed. Finally, it is remarkable how cereals contribute specially to calorie intake by means of high content in complex carbohydrates; in addition, they are an important source of proteins, which need to be complemented with other proteins of vegetable and/or animal origin, since they are low biological value proteins, as well as dietary fibre, minerals (iron, magnesium and selenium) and B-complex vitamins (thiamine, riboflavin, niacin, pyridoxine and folate). Therefore, at the same time meat consumption is moderated, cereals intake (breakfast, bread, rice, pasta) should be encouraged in order to increase, on one side, its calorie percentage contribution and, on the other side, to average the origin of protein content in the diet. In addition, it would contribute to raise calcium intake and compensate the hypothetical lower contribution of B-complex vitamins from meats.

Consumption of the rest of the food groups among surveyed students, except for sweets, bakery and pastry, was obviously lower and would explain, in large measure, the deficient intake in iodine and fat soluble vitamins (A, D and E). For example, although nutritional value of vegetables as a source of macronutrients is limited, with the exception of tubers, which are rich in starch, they are rich in dietary fibre and vitamins $\mathrm{A}, \mathrm{E}$ and $\mathrm{C}$. In this way, their daily intake would help correct the deficiency in vitamins of the dietary model in schoolchildren. Legumes should be given an appropriate consideration due to the high content in proteins, dietary fibre, iron and calcium, vitamin E, as well as compensate the hypothetical lower intake of iron and B-complex vitamins obtained from meat. Fruits are a low calorie food group, but they stand out because of their content in dietary fibre and vitamins $\mathrm{A}, \mathrm{C}$ and $\mathrm{E}$. That is why the daily or recurrent intake would contribute to a high intake in deficient vitamins $\mathrm{A}$ and $\mathrm{E}$, besides providing Phytonutrients with antioxidant properties.

With regards to foods of animal origin and quite restricted consumption as fish, it is to be noted that, in general, have a low calorie content but contain high biological value proteins even higher than those from meat and PUFA and provide with water soluble vitamins (thiamine, riboflavin and niacin), as well as fat soluble vitamins (vitamins A and D). In addition, sea fish and shellfish are the main natural source of iodine in our diet, being also a valuable source of calcium, phosphorus and iron. Therefore, its consumption should be promoted as an essential food in schoolchildren feeding. By doing so, a higher intake of iodine -together with iodized salt-, PUFA and vitamins $\mathrm{A}$ and $\mathrm{D}$ would be guaranteed and consequently, it would contribute to better the deficient intake of these nutrients in schoolchildren.
The consumption of eggs among surveyed schoolchildren corresponds to the recommended frequency (no more than one per day and three per week). The fat content in the yolk is mainly SFA and MUFA and cholesterol and, in addition, the yolk is rich in minerals (iron, calcium, zinc and selenium) and water soluble (thiamine, riboflavin and vitamin B 12) and fat soluble vitamins (vitamins A and D). However, despite this moderated intake, they contribute noticeably to the cholesterol intake in schoolchildren diet.

Bakery and pastry intake was truly noticeable, especially in breakfast of afternoon snack of schoolchildren. The nutritional value of pastry products is quite heterogeneous, due to the great variety of ingredients and proportions used. In general, energy value is very high owing to its composition in refined sugars and fat. For instance, the quantity of SFA depends on the type of vegetable oil used (palm oil or olive oil) and the amount of cholesterol depends on the origin of the fat (lard and butter) or the addition of some ingredients (eggs). What is recommended is its occasional ingestion and, therefore, it is advisable to substitute sweet, bakery and pastry with cereals and fruits, so increasing the intake of fibre, minerals and vitamins, as well as nutrients with functional properties, and reducing noticeably the intake of cholesterol and SFA.

This dietary pattern, together with the data provided by different authors, highlight a tendency in Spanish society schoolchildren eat the available food in their houses to join up to the new occidental dietary models, which show high intake of proteins and animal fat at the expense of complex carbohydrates [22-31]. However, these nutrition deficiencies would remain corrected by increasing dairy products (milk, yoghourt, etc.), cereals (bread, rice, pasta, etc.), legumes, fruits and vegetables and fish (tuna, sardine, salmon, etc.) intake and reducing the intake of meat as well as promoting the use of olive oil as the exclusive culinary oil instead of other vegetable oils. In this way, we could guarantee a sufficient intake of all vitamins and minerals that are deficient in the dietary model of the surveyed schoolchildren.

An important conclusion emerged from this work: it is imperative to design nutrition education programs with the goal of letting general population and schoolchildren in particular become aware and ready to get healthy feeding. In order to do this, public authorities should coordinate human and/or material resources enough to attempt to maintain our traditional feeding habits and make them compatible with the new lifestyle in modern societies, encouraging nutritional counselling in primary health care and developing nutrition education programs in educational institutions. This way, schoolchildren would have excellent means to prevent disease and promote health after ending compulsory education.

\section{References}

1. Serra-Majem L, Roman B, Estruch R (2006) Scientific evidence of interventions using the Mediterranean diet: a systematic review. Nutr Rev 64: S27-47.

2. Helsing $E$ (1995) Traditional diets and disease patterns of the Mediterranean circa 1960. Am J Clin Nutr 61: 1329S-1337S.

3. Willett WC, Sacks F, Trichopoulou A, Drescher G, Ferro-Luzzi A, et al. (1995) Mediterranean diet pyramid: a cultural model for healthy eating. Am J Clin Nutr 61: 1402S-1406S.

4. Trichopoulou A, Lagiou $P$ (1997) Healthy traditional Mediterranean diet: an expression of culture, history, and lifestyle. Nutr Rev 55: 383-389.

5. Bach-Faig A, Berry EM, Lairon D, Reguant J, Trichopoulou A, et al. (2011) Mediterranean diet pyramid today. Science and cultural updates. Public Health Nutr 14: 2274-2284.

6. Sánchez-Villegas A, Bes-Rastrollo M, Martínez-González MA, Serra-Majem $L$ (2006) Adherence to a Mediterranean dietary pattern and weight gain in a follow-up study: the SUN cohort. Int J Obes (Lond) 30: 350-358. 
Citation: Durá-Travé T, Gallinas-Victoriano F, Durá-Gúrpide B (2014) Dietary Habits in School Children (9-12 Years Old) with Normal Nutritional Status an a Mediterranean Area. J Nutr Disorders Ther 4: 133. doi:10.4172/2161-0509.1000133

7. Trichopoulou A, Costacou T, Bamia C, Trichopoulos D (2003) Adherence to a Mediterranean diet and survival in a Greek population. N Engl J Med 348 : 2599-2608.

8. Tur JA, Serra-Majem L, Romaguera D, Pons A (2005) Does the diet of the Balearic population, a Mediterranean type diet, still provide adequate antioxidant nutrient intakes? Eur J Nutr 44: 204-213.

9. Tur JA, Romaguera D, Pons A (2004) Food consumption patterns in a mediterranean region: does the mediterranean diet still exist? Ann Nutr Metab 48: 193-201.

10. Kris-Etherton P, Eckel RH, Howard BV, St Jeor S, Bazzarre TL (2001) Lyon diet heart study. Benefits of a mediterranean-style, national cholesterol education program/american heart association step I dietary pattern on cardiovascular disease. Circulation 103: 1823-1825.

11. Estruch R, Martínez-González MA, Corella D, Salas-Salvadó J, Ruiz-Gutiérrez $V$, et al. (2006) Effects of a Mediterranean-style diet on cardiovascular risk factors: a randomized trial. Ann Intern Med 145: 1-11.

12. Gil A, Ortega RM, Maldonado J (2011) Wholegrain cereals and bread: a due of the Mediterranean diet for the prevention of chronic diseases. Public Health Nutr 14: 2316-2322.

13. van den Brandt PA (2011) The impact of a Mediterranean diet and healthy lifestyle on premature mortality in men and women. Am J Clin Nutr 94: 913-920.

14. Kontou N, Psaltopoulou T, Panagiotakos D, Dimopoulos MA, Linos A (2011) The mediterranean diet in cancer prevention: a review. J Med Food 14: 10651078.

15. Kastorini CM, Milionis HJ, Esposito K, Giugliano D, Goudevenos JA, et al. (2011) The effect of Mediterranean diet on metabolic syndrome and its components: a meta-analysis of 50 studies and 534,906 individuals. J Am Coll Cardiol 57: 1299-1313.

16. SUVIMAX. Portions Alimentaires. Manuel photos pourl'estimation des quantités. Paris: Polytechnica; 2002.

17. Centre d'Superior Ensenyament of nutritional dietary i. Nutritional calculation program CESNID 1.0 (CD-ROM). Barcelona. Universitat de BarcelonaMcGraw-Hill; 2003

18. http://dsld.nIm.nih.gov/dsld/docs/Dietary_Reference_Intakes_Recommended_ Intakes for_Individuals.pdf

19. Reilly JJ, Dorosty AR, Emmett PM; Avon Longitudinal Study of Pregnancy and Childhood Study Team (2000) Identification of the obese child: adequacy of the body mass index for clinical practice and epidemiology. Int J Obes Relat Metab Disord 24: 1623-1627.

20. Marrodán Serrano MD, Mesa Santurino MS, Alba Díaz JA, Ambrosio Soblechero B, Barrio Caballero PA, et al. (2006) [Obesity screening: updated criteria and their clinical and populational validity]. An Pediatr (Barc) 65: 5-14.

21. Calañas-Continente A, José Arrizabalaga J, Caixàs A, Cordido F; Grupo de Trabajo sobre Obesidad de la Sociedad Española de Endocrinología y Nutrición (2010) [Diagnostic and therapeutic recommendations for overweight and obesity during adolescence. Grupo de Trabajo sobre Obesidad de la Sociedad Española de Endocrinología y Nutrición ]. Med Clin (Barc) 135: 265-273.

22. Rodriguez F, Banegas JR, Graciani MA, Hernández Vecino R, Rey Calero (1996) Consumo de alimentos y nutrientes en España en el periodo 19401988. Análisis de su consistencia con la dieta mediterránea. Med Clin (Barc) 106: 161-168.

23. Iturbe Lete A, Emparanza Knörr J, Perales Antón A (1999) [Dietary pattern of adolescents in Guipuzcoa]. An Esp Pediatr 50: 471-478.

24. Serra-Majem L, García-Closas R, Ribas L, Pérez-Rodrigo C, Aranceta J (2001) Food patterns of Spanish schoolchildren and adolescents: The enKid Study. Public Health Nutr 4: 1433-1438.

25. Durá Travé T (2001) [Energy and nutrient intake in compulsory high schoo students]. An Esp Pediatr 54: 547-554.

26. Aranceta J (2001) Spanish food patterns. Public Health Nutr 4: 1399-1402.

27. Sánchez-Villegas A, Martinez JA, De Irala J, Martínez-González MA (2002) Determinants of the adherence to an "a priori" $\mathrm{j}$ defined Mediterranean dietary pattern. Eur J Nutr 41: 249-257.

28. Serra-Majem L, Ribas L, Ngo J, Ortega RM, García A, et al. (2004) Food, youth and the Mediterranean diet in Spain. Development of KIDMED, Mediterranean Diet Quality Index in children and adolescents. Public Health Nutr 7: 931-935.

29. Mariscal-Arcas M1, Rivas A, Velasco J, Ortega M, Caballero AM, et al. (2009) Evaluation of the Mediterranean Diet Quality Index (KIDMED) in children and adolescents in Southern Spain. Public Health Nutr 12: 1408-1412.

30. Velasco J, Mariscal-Arcas M, Rivas A, Caballero ML, Hernández-Elizondo $\mathrm{J}$, et al. (2009) [Assessment of the diet of school children from Granada and influence of social factors]. Nutr Hosp 24: 193-199.

31. Diaz AA, Travé TD (2010) [Quality of dietary habits (adherence to mediterranean diet) in pupils of compulsory secondary education]. An Sist Sanit Navar 33: 35-42. 